\title{
Uso de Chatbots Personalizados para Monitoração do Desaprendizado e Esquecimento de Idosos
}

\author{
Noemi da Paixão Pinto ${ }^{1}$, Ana Cristina Bicharra Garcia ${ }^{1,2}$ \\ ${ }^{1}$ Departamento de Informática Aplicada - Universidade Federal do Estado \\ do Rio de Janeiro (UNIRIO) \\ 22.290-240 - Rio de Janeiro - RJ - Brasil \\ ${ }^{2}$ Professora orientadora \\ \{noemidpp\}@edu.unirio.br, \{cristina.bicharra\}@uniriotec.br
}

\begin{abstract}
The world population ageing may result in health problems, such as cognitive impairment, and it requires some attention. Related studies in the literature show that the advances in artificial intelligence allow the usage of technologies, like chatbots, for instance, to automate the dialogue and stimulate cognitive abilities of users. This study describes an initial research about the usage of personalized chatbots to monitor the forgetfulness and unlearning of the elderly. Through the Design Science Research approach, the main elements and steps were described to guarantee the scientific and technological contribution of this study.
\end{abstract}

Resumo. Com o envelhecimento da população mundial, problemas na área da saúde como o comprometimento cognitivo, precisam de atenção. Trabalhos relacionados ao tema mostram que os avanços na área de inteligência artificial, permite o uso de tecnologias, como os chatbots, para automatizar o diálogo e estimular as habilidades cognitivas dos usuários. Sendo assim, este artigo descreve um desenho de pesquisa para o uso de chatbots personalizados aplicados na monitoração do esquecimento e desaprendizado de idosos. Através da abordagem Design Science Research, foram apresentados os principais elementos e etapas para garantir a contribuição científica e tecnológica do presente estudo.

\section{Introdução}

Um dos eventos que têm sido observados nas últimas décadas, é o envelhecimento da população mundial. Um levantamento feito pela Organização Mundial de Saúde (WHO - World Health Organization) mostrou que há cerca de 1 bilhão de pessoas com 60 anos ou mais, representando $13,5 \%$ do número de pessoas em todo o mundo ${ }^{1}$. Projeções para 2050 mostram que uma a cada cinco pessoas terá 60 anos ou mais, chegando a um total de 2 bilhões de idosos ${ }^{2}$. Esse evento pode afetar a sociedade em diferentes áreas, incluindo a saúde.

Dentre algumas das dificuldades enfrentadas pelos idosos nessa área, estão as doenças que causam algum tipo de comprometimento cognitivo, como a demência. Essa

\footnotetext{
${ }^{1}$ www.who.int/publications/m/item/decade-of-healthy-ageing-baseline-report

${ }^{2}$ www.who.int/ageing/global-strategy/en/
} 
doença pode afetar a memória, pensamento, aprendizagem e comportamento, além de atingir a capacidade de realizar atividades cotidianas. Dentre os fatores que podem contribuir para o desenvolvimento da demência estão o isolamento social e inatividade cognitiva [WHO 2019]. Ambos podem ser causados por não ter a presença de familiares e amigos disponíveis para conversar ou realizar atividades em conjunto com os idosos [Khosravi et al. 2016]. Dessa forma, existe uma motivação para a busca de soluções que permitam o diálogo de forma automatizada para a atenuar esses fatores.

Devido aos avanços na área de inteligência artificial, tecnologias como os chatbots têm sido usadas para criar uma conversa entre um agente virtual e um usuário. Esses sistemas estão em constante processo de aprendizado através da experiência obtida pelas interações [Pereira and Diaz 2019].

A personalização de chatbots é outra vantagem na utilização desses agentes. Em [Kocaballi et al. 2019], são citados quatro diferentes tipos de personalização. Na personalização de conteúdo, as informações fornecidas pelo chatbot são ajustadas conforme o diálogo com o usuário, como por exemplo, orientações médicas. $\mathrm{Na}$ personalização de interface, a maneira como a informação é apresentada pode ser ajustada conforme a necessidade do usuário, como por exemplo, o tamanho da letra usada no visor. Já a personalização de dispositivos, faz o ajuste da mídia usada para fornecer as informações, como a escolha de voz ou texto para comunicação com o usuário. No caso da personalização de funcionalidade, diferentes objetivos podem ser encontrados em um mesmo agente, como por exemplo, um chatbot pode ser um assistente pessoal ou um agente motivacional.

A literatura apresenta trabalhos para melhorar a capacidade cognitiva de pessoas que sofrem de doenças que afetam o sistema cognitivo. Algumas soluções encontradas, estão voltadas para tratamento através de estímulo cognitivo ou diagnóstico da doença, através do uso de robôs e câmeras [Salichs et al. 2016, Montenegro and Argyriou 2017a, Griol and Molina 2015, Tsai and Lin 2018a]. Porém, observar indícios do desaprendizado e esquecimento através da monitoração automatizada de um idoso, pode ser uma forma de prevenção e alerta, antes que haja um agravamento dos sintomas.

Sendo assim, este artigo tem como objetivo descrever um desenho de pesquisa para estudar como o uso de chatbots personalizados pode auxiliar na monitoração do desaprendizado e esquecimento de um idoso. A personalização citada é referente à inclusão de conteúdo sobre a vida dos idosos, como nomes e relatos de experiências, além de assuntos de interesse deste usuário. A hipótese é que através da personalização, haja um aumento na aceitação dessa tecnologia por idosos, trazendo um diálogo mais realista e atrativo, fazendo com que o usuário interaja com o sistema por mais tempo.

\section{Trabalhos Relacionados}

$\mathrm{Na}$ literatura existem trabalhos de chatbots voltados para idosos com diferentes objetivos, mas relacionados ao tema desta pesquisa. Um dos objetivos encontrado na literatura é a monitoração de idosos já com algum tipo de comprometimento [Montenegro and Argyriou 2017b, Tsai and Lin 2018b]. Esses chatbots analisam dados dos usuários, propondo mudanças em sua rotina, saúde, tratamento ou comportamento.

A literatura também apresenta estudos de chatbots para idosos com 
diferentes tipos de personalização. Em agentes onde o conteúdo personalizado são informações na área da saúde [Sanders and Martin-Hammond 2019, Constantin et al. 2019, Miura et al. 2019, Balsa et al. 2019]. Outros chatbots fornecem instruções personalizadas para realização de exercícios físicos [Bickmore et al. 2005, Fasola and Mataric 2012, Ofli et al. 2015, Lewis et al. 2016] e cognitivos [Griol and Callejas 2016, Mostajeran et al. 2020]. Essas informações são adaptadas de acordo com vários dados do usuário, como histórico de uso [Sanders and Martin-Hammond 2019], emoções [Lee et al. 2017], dificuldade [Mostajeran et al. 2020] ou preferências [Lewis et al. 2016].

Considerando a personalização de interface, observou-se que alguns chatbots são capazes de adaptar suas características, como expressar emoções por meio da voz [Bott et al. 2019], expressões faciais [Kopp et al. 2018], posturas e gestos [De Carolis et al. 2017]. Essas adaptações são feitas com base no toque [McGlynn et al. 2017, Wada et al. 2005, Kidd et al. 2006], fala [El Kamali et al. 2018] ou emoções [Fielding et al. 2016] do usuário.

Já a personalização de funcionalidade foi encontrada em [Tsai and Lin 2018b]. Os autores desenvolveram um agente para realização de exercícios e avaliações cognitivas, para monitoração, assistência para atividades diárias, além de reabilitação e avaliação cognitiva. Uma das vantagens seria um aumento na independência desse paciente e redução dos custos com cuidadores. No caso da personalização de mídia, o chatbot proposto em [Griol and Callejas 2016], permitiu a escolha de texto ou voz como formato de entrada em caso de dificuldades.

\section{Design Science Research}

Com o intuito de garantir que o desenvolvimento do artefato, além de atuar no problema de pesquisa definido, também seja usado para contribuir com a geração de conhecimento científico, a abordagem Design Science Research (DSR) [Wieringa 2014] foi escolhida nesta pesquisa. O modelo da DSR adotado, foi baseado na proposta feita em [Pimentel et al. 2020], apresentando os principais elementos e etapas para garantir a contribuição científica deste estudo.

$\mathrm{O}$ artefato é um dos elementos principais de uma pesquisa com abordagem DSR. Neste estudo, o artefato a ser desenvolvido é um chatbot capaz de aprender a persona do idoso, monitorando também indícios de esquecimento ou desaprendizado. Através desse sistema, o idoso receberá estímulo cognitivo com informações personalizadas. A verificação desse artefato, será por meio de entrevistas com profissionais, familiares e idosos, além de experimentos com idosos sem diagnóstico de comprometimento cognitivo. Para ser aceito como uma solução viável, algumas questões guiarão a avaliação do artefato: "O chatbot consegue aprender durante o diálogo com o idoso?", "Com o uso do chatbot é possível medir o quanto o idoso está esquecendo e desaprendendo?" e "O chatbot consegue prender a atenção do idoso durante o diálogo?”.

Com base na teoria Social Cognitiva [Bandura 1977], foram listadas três conjecturas comportamentais para fundamentar o desenvolvimento do artefato. A primeira delas é que o idoso estimula suas habilidades cognitivas através de diálogos com o chatbot. A segunda é que o modelo de chatbot aprende informações sobre o idoso, e retorna essas informações como perguntas na tentativa de monitorar o quanto esse usuário 
não está desaprendendo e esquecendo. A terceira conjectura é que o idoso interage por mais tempo com o chatbot personalizado sem ter medo de errar, por lidar com um agente virtual, ao invés de um humano.

\section{Conclusão e Melhorias Futuras}

O presente artigo descreveu um desenho de pesquisa para o uso de chatbots personalizados, voltados para monitoração do desaprendizado e esquecimento de idosos. Os trabalhos relacionados mostraram que ainda há espaço para o desenvolvimento de um agente de conversação voltado para idosos, ainda sem diagnóstico de comprometimento cognitivo. Esse chatbot poderia também ser usado como uma ferramenta que, através do diálogo, estimule habilidades cognitivas de idosos. O uso de dados personalizados, como nomes de pessoas próximas, relatos de experiências vividas e assuntos de interesse, pode ser uma estratégia para que esse usuário se sinta mais à vontade, interagindo por mais tempo. A abordagem DSR foi usada para a descrição inicial dos principais elementos e etapas do presente estudo, e permanecerá em uso durante o seu andamento como forma de garantir as contribuições tecnológicas e científicas.

Uma vez que o desenvolvimento do chatbot e os procedimentos experimentais tenham sido concluídos, uma atualização deste artigo será submetida descrevendo os resultados alcançados. A ética é um importante fator a ser considerado neste estudo, já que dados pessoais dos idosos, como suas experiências de vida, serão usados para formar a base de conhecimento do chatbot. O respeito às limitações dos idosos, também precisa ser considerado.

\section{Referências}

Balsa, J., Neves, P., Félix, I., Guerreiro, M. P., Alves, P., Carmo, M. B., Marques, D., Dias, A., Henriques, A., and Cláudio, A. P. (2019). Intelligent virtual assistant for promoting behaviour change in older people with $\mathrm{t} 2 \mathrm{~d}$. In EPIA Conference on Artificial Intelligence, pages 372-383.

Bandura, A. (1977). Self-efficacy: toward a unifying theory of behavioral change. volume 84, page 191. American Psychological Association.

Bickmore, T. W., Caruso, L., Clough-Gorr, K., and Heeren, T. (2005). 'it's just like you talk to a friend'relational agents for older adults. volume 17, pages 711-735. OUP.

Bott, N., Wexler, S., Drury, L., Pollak, C., Wang, V., Scher, K., and Narducci, S. (2019). A protocol-driven, bedside digital conversational agent to support nurse teams and mitigate risks of hospitalization in older adults: Case control pre-post study. volume 21, page e13440. JMIR Publications Inc., Toronto, Canada.

Constantin, A., Lai, C., Farrow, E., Alex, B., Pel-Littel, R., Nap, H. H., and Jeuring, J. (2019). "why is the doctor a man"reactions of older adults to a virtual training doctor. In Extended Abstracts of the 2019 CHI Conference on Human Factors in Computing Systems, pages 1-6.

De Carolis, B., Ferilli, S., and Palestra, G. (2017). Simulating empathic behavior in a social assistive robot. volume 76, pages 5073-5094. Springer.

El Kamali, M., Angelini, L., Caon, M., Andreoni, G., Khaled, O. A., and Mugellini, E. (2018). Towards the nestore e-coach: a tangible and embodied conversational agent 
for older adults. In Proceedings of the 2018 ACM International Joint Conference and 2018 International Symposium on Pervasive and Ubiquitous Computing and Wearable Computers, pages 1656-1663.

Fasola, J. and Mataric, M. J. (2012). Using socially assistive human-robot interaction to motivate physical exercise for older adults. volume 100, pages 2512-2526. IEEE.

Fielding, B., Kinghorn, P., Mistry, K., and Zhang, L. (2016). An enhanced intelligent agent with image description generation. In International Conference on Intelligent Virtual Agents, pages 110-119.

Griol, D. and Callejas, Z. (2016). Mobile conversational agents for context-aware care applications. volume 8, pages 336-356. Springer.

Griol, D. and Molina, J. M. (2015). An ambient assisted living mobile application for helping people with alzheimer. In International conference on practical applications of agents and multi-agent systems, pages 3-14.

Khosravi, P., Rezvani, A., and Wiewiora, A. (2016). The impact of technology on older adults' social isolation. volume 63, pages $594-603$.

Kidd, C. D., Taggart, W., and Turkle, S. (2006). A sociable robot to encourage social interaction among the elderly. In Proceedings 2006 IEEE International Conference on Robotics and Automation, 2006. ICRA 2006., pages 3972-3976.

Kocaballi, A. B., Berkovsky, S., Quiroz, J. C., Laranjo, L., Tong, H. L., Rezazadegan, D., Briatore, A., and Coiera, E. (2019). The personalization of conversational agents in health care: Systematic review. volume 21, page e15360.

Kopp, S., Brandt, M., Buschmeier, H., Cyra, K., Freigang, F., Krämer, N., Kummert, F., Opfermann, C., Pitsch, K., Schillingmann, L., et al. (2018). Conversational assistants for elderly users-the importance of socially cooperative dialogue. In Proceedings of the AAMAS Workshop on Intelligent Conversation Agents in Home and Geriatric Care Applications co-located with the Federated AI Meeting, volume 2338.

Lee, M. C., Yeh, S. C., Chiu, S. Y., and Chang, J. W. (2017). A deep convolutional neural network based virtual elderly companion agent. In Proceedings of the 8th ACM on Multimedia Systems Conference, pages 235-238.

Lewis, L., Metzler, T., and Cook, L. (2016). Results of a pilot study with a robot instructor for group exercise at a senior living community. In International Conference on Practical Applications of Agents and Multi-Agent Systems, pages 3-14.

McGlynn, S. A., Kemple, S., Mitzner, T. L., King, C.-H. A., and Rogers, W. A. (2017). Understanding the potential of paro for healthy older adults. volume 100, pages 33-47. Elsevier.

Miura, C., Maeda, H., Saiki, S., Nakamura, M., and Yasuda, K. (2019). Prototyping and preliminary evaluation of mind monitoring service for elderly people at home. In Proceedings of the 21st International Conference on Information Integration and Web-based Applications \& Services, pages 437-443.

Montenegro, J. M. F. and Argyriou, V. (2017a). Cognitive evaluation for the diagnosis of alzheimer's disease based on turing test and virtual environments. volume 173, pages 42-51. Elsevier. 
Montenegro, J. M. F. and Argyriou, V. (2017b). Cognitive evaluation for the diagnosis of alzheimer's disease based on turing test and virtual environments. volume 173, pages 42-51. Elsevier.

Mostajeran, F., Steinicke, F., Ariza Nunez, O. J., Gatsios, D., and Fotiadis, D. (2020). Augmented reality for older adults: Exploring acceptability of virtual coaches for home-based balance training in an aging population. In Proceedings of the $2020 \mathrm{CHI}$ Conference on Human Factors in Computing Systems, pages 1-12.

Ofli, F., Kurillo, G., Obdržálek, Š., Bajcsy, R., Jimison, H. B., and Pavel, M. (2015). Design and evaluation of an interactive exercise coaching system for older adults: lessons learned. volume 20, pages 201-212. IEEE.

Pereira, J. and Diaz (2019). Using health chatbots for behavior change: A mapping study,. volume 43.

Pimentel, M., Filippo, D., and Santos, T. M. (2020). Design science research: pesquisa científica atrelada ao design de artefatos. volume 3, pages 37-61.

Salichs, M. A., Encinar, I. P., Salichs, E., Castro-González, Á., and Malfaz, M. (2016). Study of scenarios and technical requirements of a social assistive robot for alzheimer's disease patients and their caregivers. volume 8, pages 85-102. Springer.

Sanders, J. and Martin-Hammond, A. (2019). Exploring autonomy in the design of an intelligent health assistant for older adults. In Proceedings of the 24th International Conference on Intelligent User Interfaces: Companion, pages 95-96.

Tsai, Y.-T. and Lin, W.-A. (2018a). Design of an intelligent cognition assistant for people with cognitive impairment. In 2018 IEEE 20th International Conference on High Performance Computing and Communications; IEEE 16th International Conference on Smart City; IEEE 4th International Conference on Data Science and Systems (HPCC/SmartCity/DSS), pages 1207-1212.

Tsai, Y.-T. and Lin, W.-A. (2018b). Design of an intelligent cognition assistant for people with cognitive impairment. In 2018 IEEE 20th International Conference on High Performance Computing and Communications; IEEE 16th International Conference on Smart City; IEEE 4th International Conference on Data Science and Systems (HPCC/SmartCity/DSS), pages 1207-1212.

Wada, K., Shibata, T., Saito, T., Sakamoto, K., and Tanie, K. (2005). Psychological and social effects of one year robot assisted activity on elderly people at a health service facility for the aged. In Proceedings of the 2005 IEEE international conference on robotics and automation, pages 2785-2790.

WHO (2019). Global action plan on the public health response to dementia 2017-2025. https://www.who.int/mental_health/neurology/dementia/guidelines_risk_reduction/en/ (Acesso em 07/12/2020).

Wieringa, R. J. (2014). Design science methodology for information systems and software engineering. Springer. 